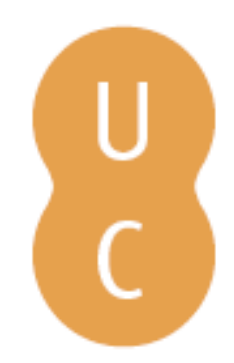

\title{
nombalina
}

\section{Nutrient dynamics in the intertidal pools of the Mondego estuary: II - seasonal efflux of PO4-P and NH4-N in bare bottom and vegetated pools}

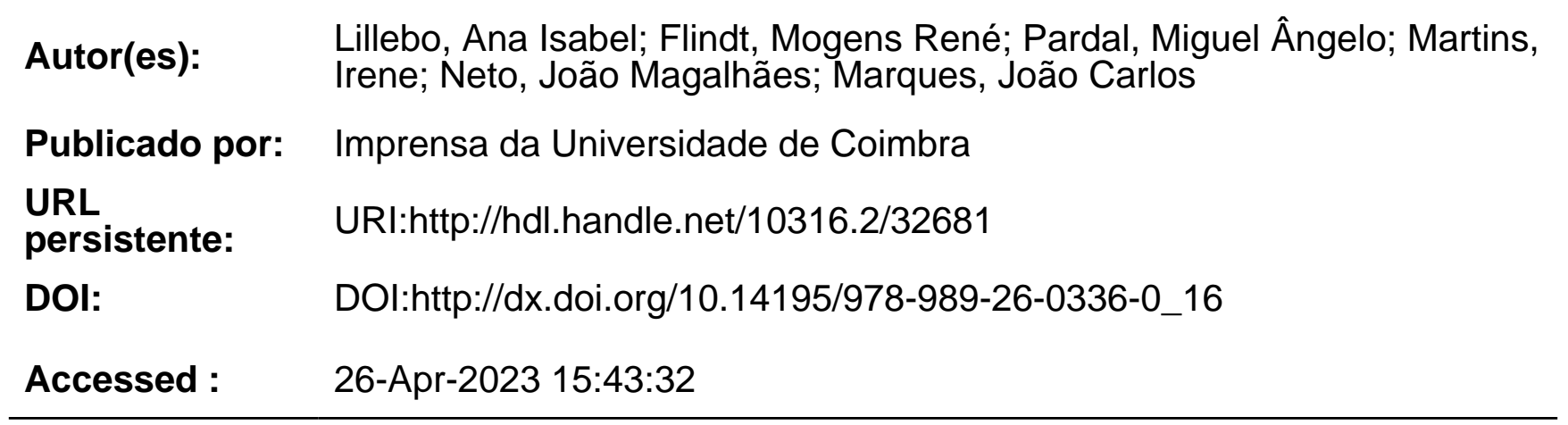

A navegação consulta e descarregamento dos títulos inseridos nas Bibliotecas Digitais UC Digitalis, UC Pombalina e UC Impactum, pressupõem a aceitação plena e sem reservas dos Termos e Condições de Uso destas Bibliotecas Digitais, disponíveis em https://digitalis.uc.pt/pt-pt/termos.

Conforme exposto nos referidos Termos e Condições de Uso, o descarregamento de títulos de acesso restrito requer uma licença válida de autorização devendo o utilizador aceder ao(s) documento(s) a partir de um endereço de IP da instituição detentora da supramencionada licença.

Ao utilizador é apenas permitido o descarregamento para uso pessoal, pelo que o emprego do(s) título(s) descarregado(s) para outro fim, designadamente comercial, carece de autorização do respetivo autor ou editor da obra.

Na medida em que todas as obras da UC Digitalis se encontram protegidas pelo Código do Direito de Autor e Direitos Conexos e demais legislação aplicável, toda a cópia, parcial ou total, deste documento, nos casos em que é legalmente admitida, deverá conter ou fazer-se acompanhar por este aviso.

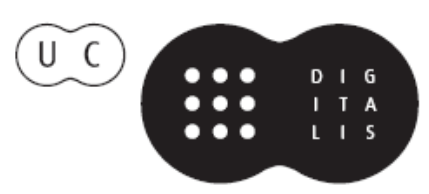


MIGUEL ÂNGELO PARDAL JOÄO CARLOS MARQUES MANUEL AUGUSTO GRAÇA Scientific Editors

\section{Aquatic Ecology of the Mondego River Basin Global Importance of Local Experience}




\author{
MIGUEL ÂNGELO PARDAL \\ JOẢO CARLOS MARQUES \\ MANUEL AUGUSTO GRAÇA \\ Scientific Editors
}

\title{
Aquatic Ecology of the Mondego River Basin Global Importance of Local Experience
}




COORDENAÇÃO EDITORIAL
Imprensa da Universidade de Coimbra
CONCEPÇÃO GRAFICA
António Barros
INFOGRAFIA
António Resende
Estimulus [design] • Coimbra
EXECUÇÃO GRAFICA
GRAFIASA
ILUSTRAÇÃO DA CAPA
P. P. Cunha e ]. Dinis
ISBN
972-8704-04-6
DEPOSITO LEGAL
I75038/02

(C) JANEIRO 2002, IMPRENSA DA UnIVERSIDADE DE COIMBRA

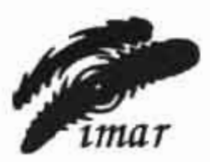

CPIMAR

imar

OBRA PUBLICADA COM O PATROCINIO DE:

IMAR - INSTITUTO DO MAR

IPIMAR - INSTITUTO DE INVESTIGAÇĀO DAS PESCAS E DO MAR 



\author{
ANA ISABEL LILLEBø ' \\ MOGENS RENE FUINDT ${ }^{2}$ \\ Miguel. ÂNGELO PARDAL ' \\ IRENE MARTINS ' \\ joảo Magalmäes neto ' \\ joáo Carlos Marques '
}

\title{
NUTRIENT DYNAMICS INTHE INTERTIDAL POOLS \\ OFTHE MONDEGO ESTUARY. \\ ॥ - SEASONAL EFFLUX OF PO ${ }_{4}-\mathrm{P}$ AND $\mathrm{NH}_{4}-\mathrm{N}$ IN BARE BOTTOM AND VEGETATED POOLS
}

\begin{abstract}
In intertidal estuaries, such as the Mondego estuary, not much is known about the importance of the low water intertidal pools, with regard to sediment/water exchanges of ammonia and phosphate, as a result of anabolic/catabolic balances. Therefore, the main topic of this work was a comparative study of the role and the importance of the nutrient efflux in intertidal bare bottom (sandy and muddy) and in Spartina maritima covered pools, during day and night periods. Seasonal variation and daily variations were studied in July and November 1997.

Although, the availability of nutrients is reflected by the organic content in sediments, S. maritima dynamics clearly influence ammonia and phosphate efflux rates, especially in summer and during the day. Considering the fact that sediments constitute a major source of nutrients for rooted macrophytes, during the day there might be a certain competition between two processes: Spartina maritima facilitated adsorption capacity and the efflux from the sediment.

Ammonia and phosphate fluxes were higher in bare bottom muddy pools, followed by Spartina maritima covered pool and sandy bare bottom pools. It was also possible to observe the importance of plant dynamics. Ammonia efflux rates where higher during fall, due to Spartina was less productive, while the Spartina kept the efflux low during summer (flowering season). On the system level, the results express the importance of intertidal low water pools to the internal nitrogen loading, particularly in the bare bottom muddy pools.

This study also shows that in July, high temperatures and anoxic conditions, especially during the night, promoted the phosphate efflux to the overlaying water column Moreover, S. maritima also controlled phosphate efflux from the sediment during the day, but in absence of enough light for primary production to take place, during the night, phosphate efflux increases, especially in July. Although in a seasonal scale. the daily mean

17 IMAR - Instituto do Mar, Centro Interdisciplinar de Coimbra a/c Departamento de Zoologia. Universidade de Coimbra, 3004-517 Coimbra, Portugal

a) Biological Institute, SDU . University of Odense, Campusvej 55, 5230 Odense M. Denmark.
\end{abstract}


(day/night) efflux rates were similar. On the system level, results also evidences the importance of these intertidal pools to the internal dissolved inorganic phosphate loading, especially the muddy bare bottom pools. which showed a clear seasonal variation.

\section{Introduction}

Many studies have focused on the importance of freshwater runoff from land and the exchange of water with adjacent open sea regarding biogeochemical processes in estuaries (e.g.Valiela and Teal 1979. Hinga 1990. Staver et al. 1996, Pardal 1998, Flind et al. 1999).

It is know, that in estuaries vertical distribution and relative abundance of inorganic nitrogen compounds $\left(\mathrm{NH}_{4}, \mathrm{NO}_{2}^{-}\right.$, and $\left.\mathrm{NO}_{3}^{-}\right)$in the sediment are controlled by the redox state (Valiela 1995). In anaerobic sediments ammonium is far more abundant and it has been shown that ammonium diffuses upward to the overlying water (Valiela 1995). Rocha (1998) described a mechanism where, in warm climates intertidal estuaries and during the day, temperature gradient between the exposed sediment and water at the time of flooding causes a free convection of ammonia to the water column. On the other hand, if the water is warmer than the sediment surface, which is the intertidal pool situation, ammonia efflux only occurs by diffusion (Rocha 1998).

The movement of particulate organic matter transports most of the phosphorous to the sediment. In an intertidal system, sediments get exposed to air and subsequent drying conditions during ebb tide, and it has been show (Baldwin 1996 in Mitchell and Baldwin 1998) that under this desiccated/oxidation conditions, sediments have a substantially higher phosphate sorption capacity than submerged sediments. Nevertheless, in the intertidal pools sediments are always submersed, and may represent $30-40 \%$ of the system area (Flindt et al. 2002, Lillebø et al. 2002). Phosphorus dynamics is also influenced by sediment resuspension and macrophyte coverage (Flindt and Kamp-Nilsen 1998) and bacteria might directly or indirectly mediate phosphorous release from sediments (Mitchell and Baldwin 1998). On the other hand, temperature seems to be of crucial importance to the efflux of phosphorus from the sediment (e.g. Asmus et al. 2000), with a resulting increased of phosphorus internal loading (e.g. Perttilä et al 1995, Valiela 1995. Pardal 1998. Sfriso 1988).

The importance of benthic mineralisation to the trophic chain increase as the water column gets shallower (e.g. Nixon and Pilson 1983 in Rocha 1998), and particularly in these ephemeral pools system, physic and chemical conditions change in few hours, reaching high water temperature and low oxygen concentrations, especially during summer night ebbs tides. Moreover. submersed rooted macrophytes link the nutrients in sediments with the overlying water, which may have important implications for nutrient cycling within such systems (e.g.Valiela 1995, Kamp-Nilsen and Flindt 1993. Flindt et al. 1999). But the relative contribution from the sediment pore-water and the overlying water column to N/P supply is not very well documented (Flindt et al. 1999), Therefore, the main topic of this work was a comparative study of the seasonal 
nutrient efflux in intertidal bare bottom (sandy and muddy) and macrophyte (Sportino maritima) covered pools during 24-hours tidal cycles.

\section{Material and methods}

Field procedure

In the present study Spartina maritima salt marsh area was chosen for being the most representative regarding vegetated tidal pools in the Mondego estuary (Marques et al. 2002, Pardal 1998, Lillebø et al. 1999) (Fig I). A tidal pool in this anea was selected to represent an average pool size in respect to surface area and depth. Simultaneously, the same study was performed in two bare bottom areas characterised respectively by muddy and sandy sediments. Pools were studied during 24-hours tidal cycles in July 97 and November 97, representing respectively summer and fall situations. From the pool formation until the pool was submerged again, water temperature, salinity and dissolved oxygen were measured, and water samples ( $10 \mathrm{ml}$ each) were taken for dissolved reactive phosphate and ammonia analysis. The sampling frequency was one hour. All the water samples were filtered in the field through a Whatman GF/F glassfibber filter and stored in ice. In the laboratory they were kept frozen at $-18^{\circ} \mathrm{C}$ until analysis. Each pool was measured for surface area and depth at each sampling date. Flux chambers were placed in the main channel (under day and night situations, July 2001 ) for comparison of the efflux rates in the low water pools.

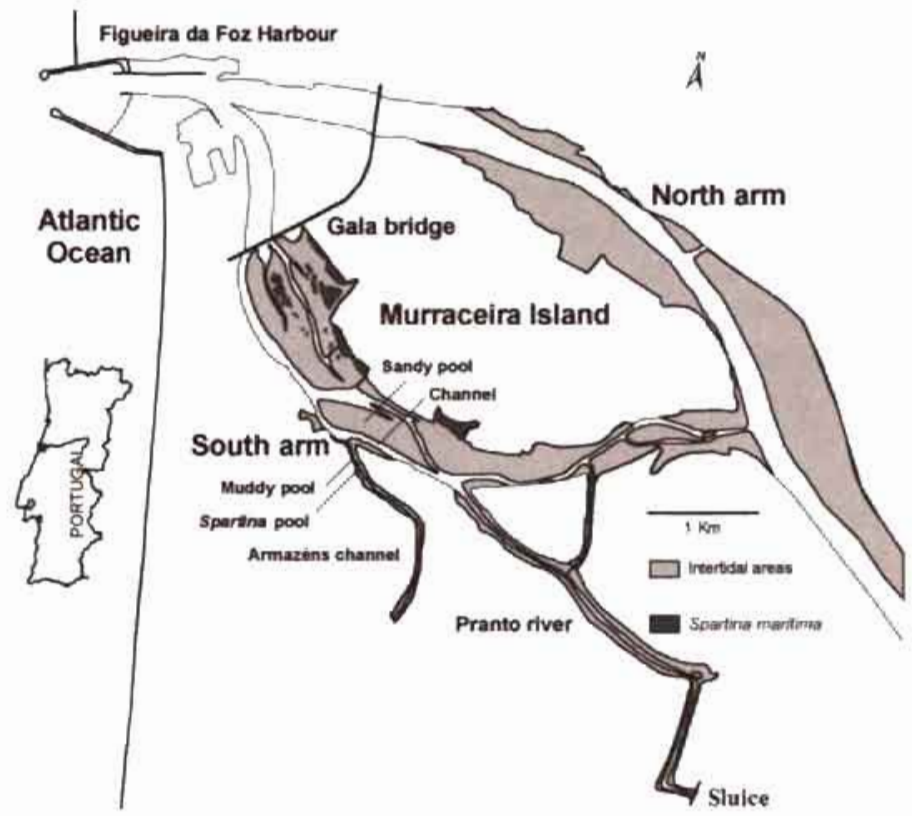

Fig 1. Spartino maritima salt marsh area in the Mondego estuary with the location of the three types of tidal pools. 


\section{Analytical procedure}

Analysis of dissolved reactive phosphate and ammonia were carried out using a rapid flow autoanalyser (RFA 300 Alpkem) and performed according to Aipkem methodologies (Alpkem. 1990).

\section{Calculations}

Phosphate, ammonia and oxygen fluxes were calculated taking into account the initial concentrations in the pool, which corresponded to the very first measurement just after the formation of the tidal pool (to). So, for each consecutive sample ( $\left.t_{1}, t_{2} . ., t_{n}\right)$ the calculated rates were given by the difference between concentration in time ( $t_{n}$ ) and the initial concentration, an then divided by the number of hours between the two samples.

$$
\text { Rate }=\left[\frac{C f-C i}{m-t o}\right]
$$

All data were previously standardised $\left(\mu \mathrm{mol} \mathrm{r}^{\prime} \mathrm{m}^{-2}\right.$ ) to avoid bias caused by differences in the pools size. For the same reason, all data were also standardised ( $\mathrm{mg} m$ $\left.{ }^{7}\right)$ to calculate the total amount of nutrients per hour,

Calculations of the mean efflux rates ( $\mathrm{mg} \cdot \mathrm{m}^{-2} \mathrm{~d}^{\prime}$ ) were performed considering: a) the mean daily efflux rates (day and night) from each type of pool (Lillebø et al. 2002); b) a visual estimation of the contribution of each type of pool to the estuarine area (1.9 $\mathrm{km}^{2}: 17 \%$ Sportina. $50 \%$ mud and $33 \%$ sand); c) a visual estimation of the area covered by pools during low tide (40\%): d) the mean efflux rates in July could represent a mean value for spring and summer, and that the mean efflux rates in November could represent a mean value for fall and winter. In the main channel it was assumed that there is no significant seasonal variation.

It is known that nutrient fluxes are strongly dependent on temperature dynamics, and several studies have demonstrated this promoting effect of rising temperatures (e.g. Nixon et al. 1976. Fisher et al, 1982 all in Asmus et al, 2000). As a preliminary approach, we therefore used a simple dynamic temperature model to simulate the yearly variation in the ammonia fluxes. The model equations are:

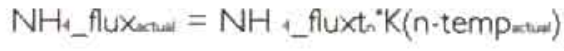

$$
\text { Accumulated } \mathrm{NH} \text { \&_flux }=\mathrm{NH}_{4} \text { flux }_{x_{+}}+\mathrm{NH}_{4} \text { _flux }
$$

Where the $\mathrm{NH}_{\text {\& }}$ flux is the measured phosphate flux at a certain temperature $\left(n^{\circ} \mathrm{C}\right), \mathrm{K}$ is temperature dependency constant, while tempana is the simulated ammonia fluxes. $K$ vaned between $1.02-1.12$ indicating that some pools are more temperature dependent than others. The only forcing function was the temperature. Afterward the simulated fluxes becomes numerical integrated so the yearly internal loading, due to the flux dynamics, for the pools becomes simulated. 
Calculations of the ammonia mass efflux ( $\mathrm{kg} \mathrm{N}$ ) were also performed assuming that the mean efflux rates in July could represent a mean value for spring and summer. and that the mean efflux rates in November could represent a mean value for fall and winter. In the main channel it was assumed that there is no significant seasonal variation.

\section{Results}

During the life span of the pools temperature increased dramatically during the day (Fig. 2) and, as we should expect, mean water temperature increased seasonally, reaching a maximum value of $32^{\circ} \mathrm{C}$, in july and a minimum of $10^{\circ} \mathrm{C}$ in November. Oxygen concentration decreased during the night, (always less than $\left.5 \mathrm{mg} \mathrm{O}\right|^{\prime}$ '), when primary production was unable to compensate for heterotrophic oxygen consumption. This situation was more accentuated in July when temperature was about to $20^{\circ} \mathrm{C}$, ( $\mid \mathrm{mg} \mathrm{O} \mathrm{O}_{2}$ '). So, pools become anoxic, for short periods. Salinity varied seasonally as a function of the freshwater discharges from the Pranto River (Fig. 1) (Marques et al. 2002). The lowest salinities were recorded in November, always less than 5 and the highest in July, reaching 36.

July 97
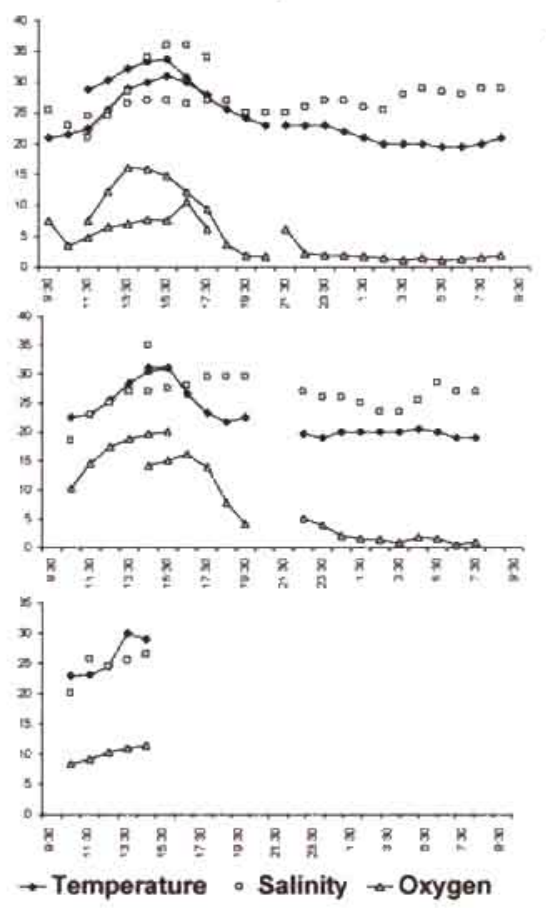

November 97

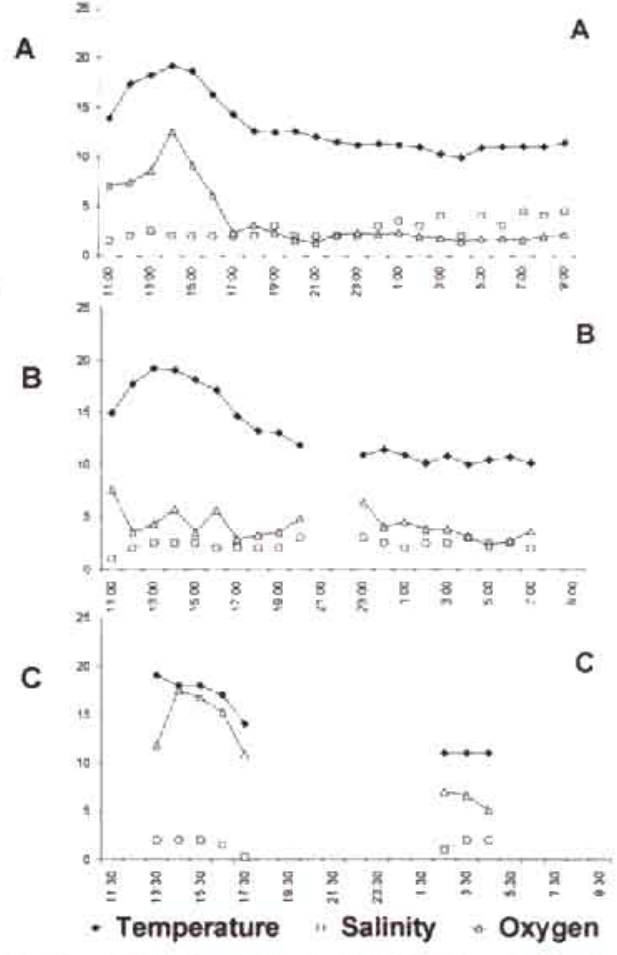

Fig 2 Seasonal varation (July and November) of water pools temperature (" $\mathrm{C}$. Salinity and Oxygen ( $\left(\mathrm{mg} \mathrm{O}_{2} \mathrm{f}^{\prime}\right)$ : a) Spartina marima covered pool. b) Muddy bare bottom pool. c) Sandy bare bottom pool. 
Ammonia dynamics

Seasonal differences were observed concerning the initial total amount of ammonium in the poois (Fig. 3). In July 97 the initial values varied between 8 and $12 \mathrm{mg}$ $\mathrm{m}^{-2}\left(579\right.$ and $724 \mu \mathrm{mol} \mathrm{m}^{2}$ ) in the Spartina covered pool, 8 and $12 \mathrm{mg} \mathrm{m}^{2}$ (547 and 742 $\mu \mathrm{mol} \mathrm{\textrm {m } ^ { 2 }}$ ) in the muddy bare bottom pool and $0.7 \mathrm{mg} \mathrm{m}^{2}\left(49 \mu \mathrm{mol} \mathrm{m} \mathrm{m}^{2}\right)$ in the sandy bare bottom pool (Fig 3). In November, we quantified $46 \mathrm{mg} \mathrm{m}^{2}\left(3275 \mu \mathrm{mol} \mathrm{m}{ }^{-2}\right)$ in the Spartina covered pool, 14 and $21 \mathrm{mg} \mathrm{m}^{2}$ ( 1009 and $1513 \mu \mathrm{mol} \mathrm{m}^{2}$ ) in the muddy bare bottom pool, and 8 and $11 \mathrm{mg} \mathrm{m} \mathrm{m}^{-2}\left(566\right.$ and $\left.812 \mu \mathrm{mol} \mathrm{m}^{2}\right)$ in the sandy bare bottom pool (fig 3). The total amount of ammonia was therefore much higher in November. Moneover, the total amount of ammonia in Spartina covered pool was much more dynamic in November. which may be a reflection of plants annual dynamics.
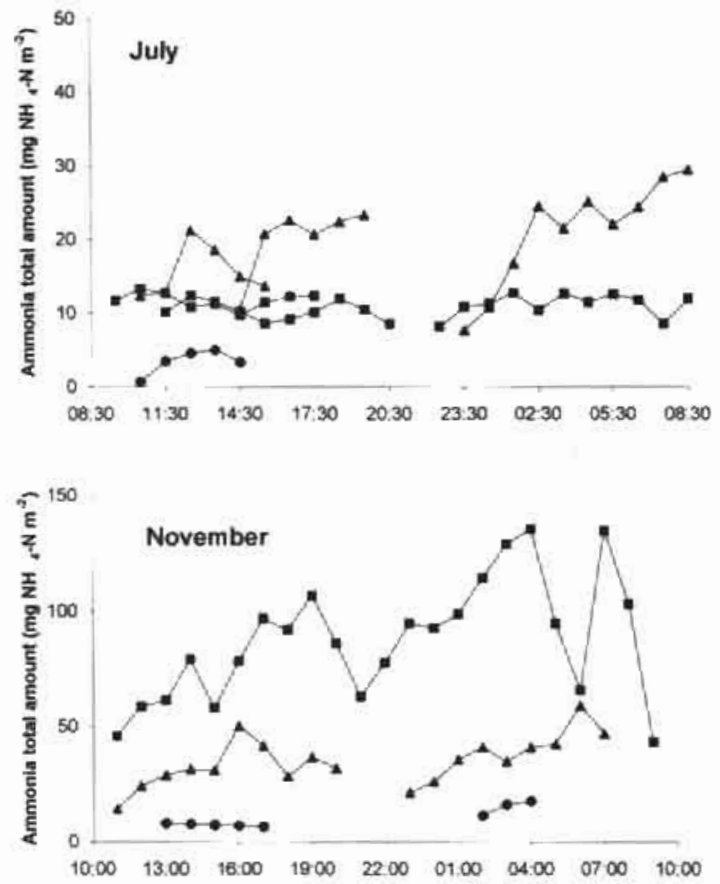

\section{-Spartina ^ Bare mud • Sand}

Fig 3 Seasonal variation of ammonia total amount ( $\mathrm{mg} \mathrm{NH}_{*}-\mathrm{N} \mathrm{mm}$ ) durng the life span of the low water pools.

Ammonia formation is close related to mineralisation, and therefore plotted against oxygen consumption.

Results show that in all three pools, higher ammonia efflux rates occurred during the night period when heterotrophic respiration was not compensated by primary production (Fig 4). Considering separately each type of pool, results showed that the 

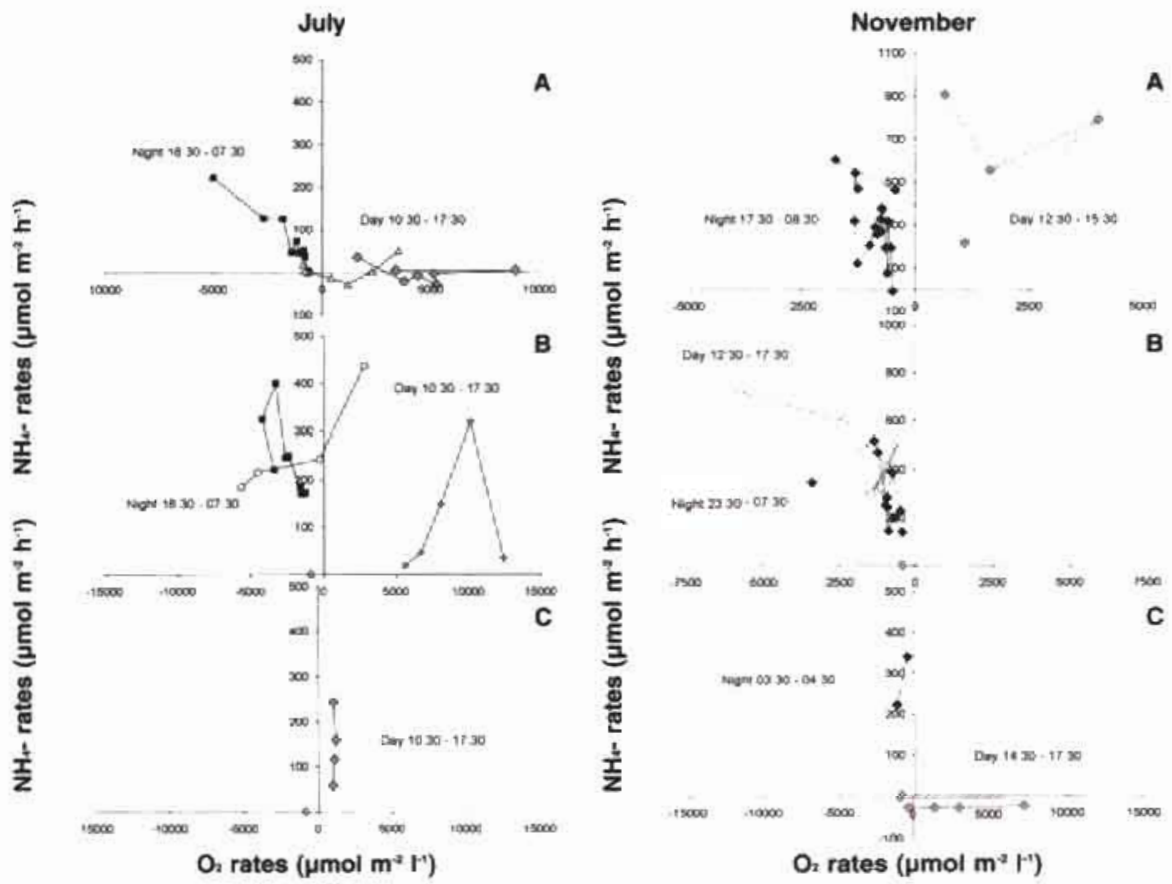

Fig 4 Seasonal vanation of ammonia efflux and uptake rates vs. oxygen efflux and uptake rates; a) Spartino mantima covered pool, b) Muddy bare bottom pool, c) Sandy bare bottom pool:

efflux rates of ammonia in the Spartina maritima covered pool was very dependent on plant dynamics. In July there was ammonia influx during the day and an efflux during the night (Fig 4.IA). Furthermore, although oxygen depletion during night was higher in July, ammonia efflux was much higher in November and occurred even during the day (Fig 4.2A). In the muddy bare bottom pool, there were always effluxes of ammonia (day and night), and oxygen concentration decreased along the life span of the pool during day and night periods (Fig 4.IB. 4.2B). Oxygen depletion was similar in july and November. In the sandy bare bottom pool, although, efflux rates during the day were lower in November, it also seemed to increase during night (Fig 4.IC, 4.2C).

Considering the mean daily efflux rates (day and night) from each type of pool there was a clear seasonal variation of the efflux rates, with higher $\mathrm{N}$-effluxes during fall and lower during summer (Fig. 5). This seasonal variation is particularly clear in the Spartina covered pool. The efflux rates measured in the main channel are comparatively very low (Fig. 5).

As a preliminary approach, we simulate the internal loading of ammonia based on a temperature-dependent model (Fig. 6). Despite cautions in interpreting this simulation, due to the lack of points for the calibration of the model, it express a decrease of ammonia efflux during the warmer periods (spring and summer) and an increase during fall and winter, especially in the Spartina covered pools. 


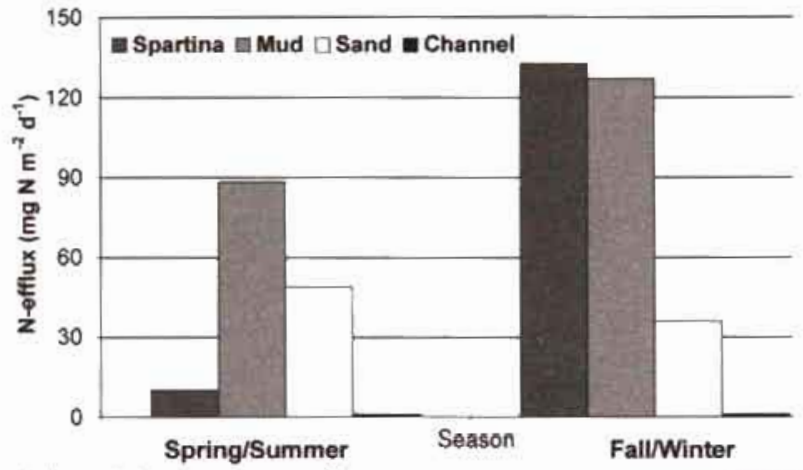

Fig 5. Seasonal variation of phosphate mean efflux rates ( $m g\left(N H_{w}-N^{2} h^{\prime}\right)$ at each pool type and the main channel.

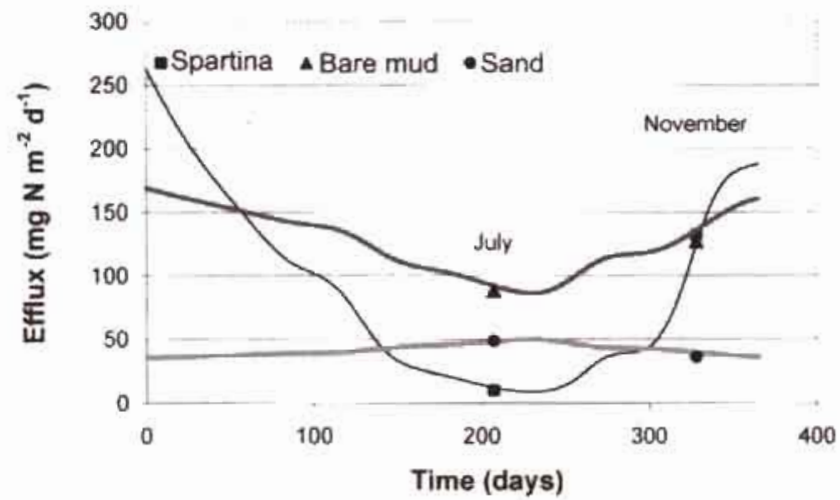

Fig 6. Simulation of the yearly variation in ammonia fluxes, in pooks located in the bare bottom muddy areas. sandy areas and in Sportina montima covered areas of the estuary

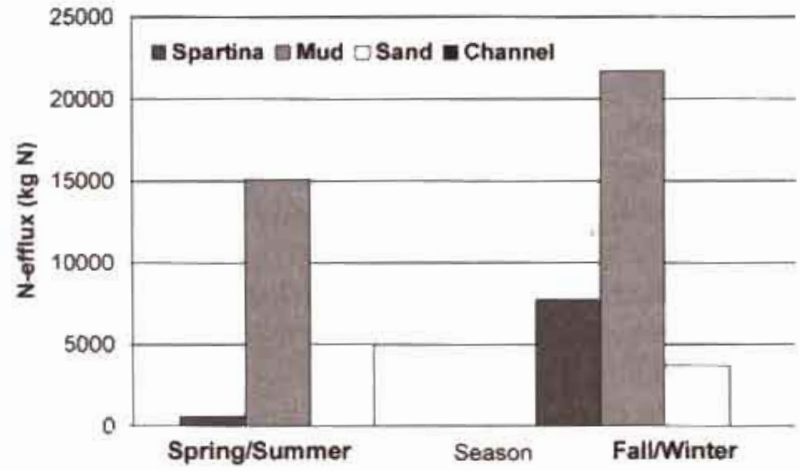

Fig 7. Yearly net efflux of ammonia ( $\mathrm{kg} \mathrm{N}$ ) for each type of pool and the main channel.

Calculations of the ammonia net effluxes $(\mathrm{kg} \mathrm{N})$, based on the simulated values, suggest a strong contribution of the bare bottom muddy pool to the whole system internal ammonia loading (Fig 7), and especially during fall and winter. The Spartuno 
covered pool and the sandy covered pool had a similar yearly contribution to the system internal ammonia loading, but higher than the channel (Fig. 7). Although, sandy pools did not show a clear seasonal variation.

Phosphate dynamics

The initial total amount of phosphate in the pools decreased from July to November in Spartina covered pool and in the bare bottom muddy pool, but increased slightly in the bare bottom sandy pool (Fig. 8). In July 97, the initial values varied between 2 and $3 \mathrm{mg} \mathrm{m} \mathrm{m}^{2}\left(115\right.$ and $126 \mu \mathrm{mol} \mathrm{m}^{2}$ ) in the Spartina maritimo covered pool, 1 and $4 \mathrm{mg} \mathrm{m}^{-1}\left(52\right.$ and $310 \mu \mathrm{mol} \mathrm{m}^{-2}$ ) in the muddy bare bottom pool and 0.8 $\mathrm{mg} \mathrm{m}^{-1}\left(55 \mu \mathrm{mol} \mathrm{m} \mathrm{m}^{2}\right.$ ) in the sandy bare bottom pool (Fig 8). In November, we quantified $4 \mathrm{mg} \mathrm{m}^{2}\left(268 \mu \mathrm{mol} \mathrm{m}^{2}\right)$ in the Spartina maritima covered pool, I $\mathrm{mg} \mathrm{m}^{2}(75 \mu \mathrm{mol} \mathrm{m}$ $\left.{ }^{2}\right)$ in the muddy bare bottom pool, and I and $1.5 \mathrm{mg} \mathrm{m}^{2}\left(85\right.$ and $\left.107 \mu \mathrm{mol} \mathrm{m}{ }^{2}\right)$ in the sandy bare bottom pool (fig 8). The phosphate total amount was therefore higher in July. Moreover, the total amount of phosphate in Spartina covered pool was much more dynamic in November, which may also reflect the plants annual dynamics.
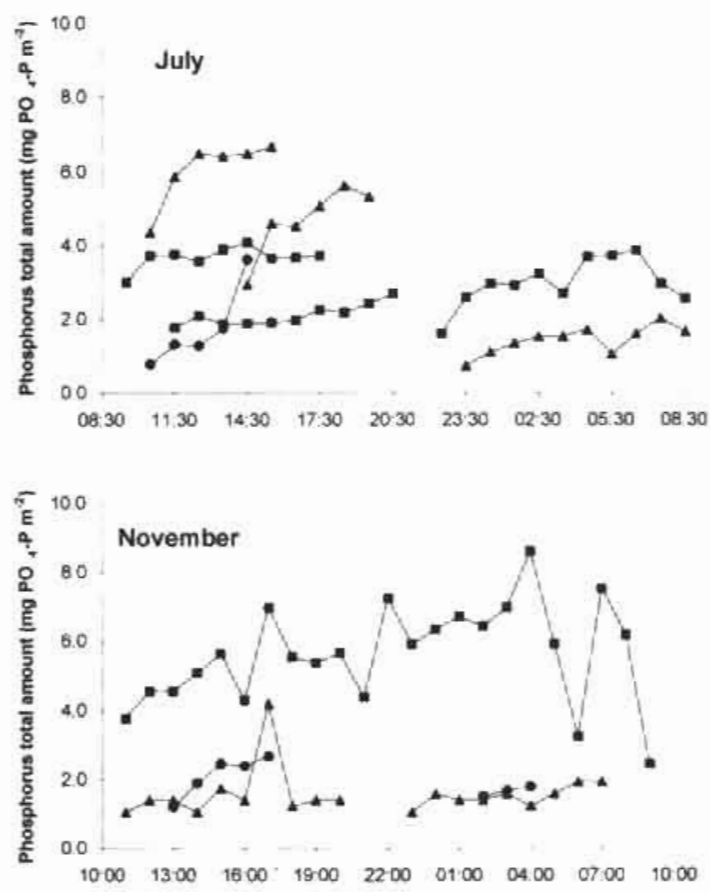

- Spartina $\Delta$ Bare mud • Sand

Fig 8 . Seasonal variation of phosphons total amount $\left(\mathrm{mg} P \mathrm{PO}_{4}-\mathrm{P} \mathrm{m}^{2}\right)$ during the life span of the low water pook. 
The comparison of phosphate and oxygen efflux rates $\left(\mu \mathrm{mol} \mathrm{m} \mathrm{m}^{-2} \mathrm{~h}^{-1}\right)$ in July and November shows that for the same type of pool, the process varies seasonally (Fig. 9). with lower efflux rates in November. Efflux rates were always higher within the first hour after pool formation. Considering each type of pool, Spartina covered pool phosphate dynamics seems much dependent on plant dynamics. In fact efflux rates are much lower during the day and increase during the night, in July (Fig. 9.IA). On the other hand, in November, although efflux rates are lower (Fig. 9.2A), higher total amount of phosphate occurred during the day and under oxic conditions (Fig. 8). In the muddy bare bottom pool there was always efflux of phosphate (Fig. 9.I B. 9.2B). In the sandy bare bottom pools, values found for the phosphate efflux were lower than in the other two types of pools, but showing the same tendency as in the bare bottom muddy pool (Fig. 9.1C, 9.2C).
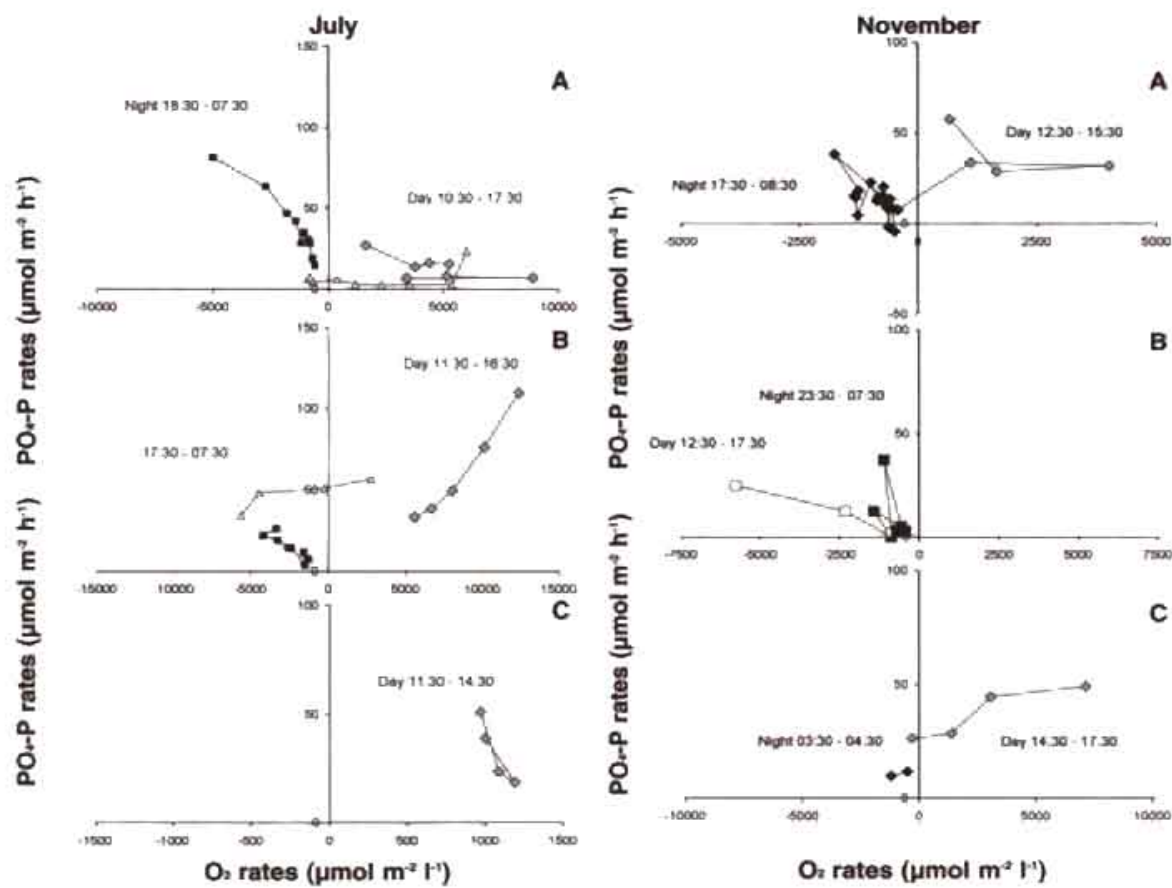

Fig 9. Seasonal variation of phosphate efflux and uptake rates vs. oxygen efflux and uptake rates: a) Spartina maritima covered pool, b) Muddy bare bottom pool, c) Sandy bare bottom pool.

Considering the mean daily efflux rates (day and night) from the muddy bare bottom pool there was a clear seasonal variation of the efflux rates, with higher $\mathrm{P}$ effluxes during Spring/Summer and lower during FallWinter (Fig. 10). This seasonal variation is not visible in the Spartina covered pool, or in the sandy pools. The efflux rates from the main channel are comparatively low (Fig. I0). 


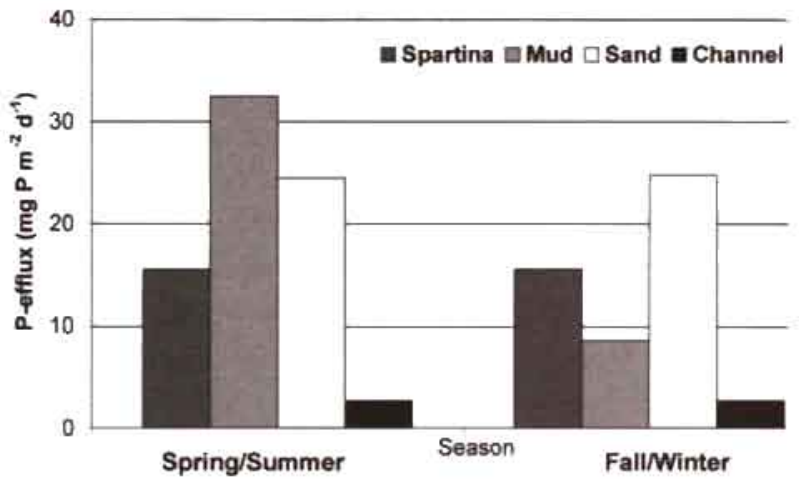

Fig 10. Seasonal variation of phosphate mean efflux rates ( $m g$ PO $\left.-\mathrm{P} \mathrm{mi}_{1} \sigma^{\prime}\right)$ at each pool type and the main channel.

\section{Discussion}

Ammonia dynamics

Results clearly show the influence of plant coverage, especially with higher temperatures and during the day. In fact, rooted macrophytes keep nutrients cycling close coupled to the hizosphere, and it is known that rooted vegetation potentially enhances denitrification (Valiela 1995, Flindt et al.1999). Moreover. ammonia can be removed from water by plants uptake, algae and bacteria, which may also explain the depressed fluxes, meaning uptake of ammonia from the water column in the Sportuna maritima covered pool. Therefore, we might expect a different nutrient dynamics between Spartina maritima covered intertidal pools and bare bottom pools (muddy and sandy sediments). Furthermore, the organic content in sediments also reflects the availability of nutrients, and results from a previous study (Flindt et al. 2002) showed that in S. moritima covered pools the organic content was about $8 \%$ in the sediment upper layer, decreasing to about $5 \%$ at $12.5 \mathrm{~cm}$ 's depth. Comparatively, muddy sediments presented an organic content of about $5 \%$ in the upper layer. decreasing to about $2 \%$ while sandy bare bottom sediments exhibited the lowest organic content with approximately $0.95 \%$ without any variations as a function of depth. All these facts may explain the higher effluxes of ammonia in bare bottom muddy pools, followed by Spartina moritima covered pools and sandy bare bottom pools. Comparatively with a study performed in the River Colne estuary, efflux rates of ammonia are in the same range ( $\mu \mathrm{mol} \mathrm{NH}_{4}-\mathrm{N} \mathrm{m}^{2} \mathrm{~h}^{\prime}$ ) respectively for sandy sediments and muddy sediments, probably as a function of organic matter content and higher ammonification rates in the sediment (Ogilvie et al. 1997). On the other hand, if we consider a day/night cycle, ammonia efflux rates are higher during the night, which is in agreement with an experimental study performed by Kristensen (1993). Furthermore, anoxic conditions occurred during the night, especially in July, so it may also be responsible for the higher ammonia efflux (Pettine 1983). On a 
seasonal scale, ammonia effluxes were always higher during winter in the muddy sediment pools (bare bottom and Spartino covered). These results are in agreement with results from Ogilvie and others (1997), which could just find this seasonal variation in a muddy sediment site with higher organic matter content, although Kristensen (1993) could not find a significant seasonal pattern. In the sandy sediment there was no clear seasonal variation in ammonia efflux, which is in agreement with results from Ria Formosa (Portugal), (Falcão and Vale, 1998), were the $\mathrm{NH}_{*}{ }^{+}$flux in sandy sediments was production-rate controlled, and the flushing from intertidal sediments was similar in February in June.

Calculations of the ammonia net effluxes $(\mathrm{kg} \mathrm{N})$, express not only the $\mathrm{N}$-efflux seasonal variation in Spartina and muddy pools, but evidences the importance of intertidal low water pools to the internal nitrogen loading, as well the clear contribution of the bare bottom covered pools to the whole system internal nitrogen loading.

Most probably differences in ammonia fluxes between the muddy bare bottom pool and the Spartino pool is due to plant associated process. Based on this difference in the temporally integrated ammonia mass, we were able to calculate the plant production in nitrogen units. Taking into account, field data from Lillebø (2000) of aboveground mean $\mathrm{C} / \mathrm{N}$-ratio (35.5) for the Spartina maritimo, we calculated the local plant production to a mean yearly net primary production of $503 \mathrm{~g} \mathrm{C} \mathrm{m}^{-2} \mathrm{y}^{\prime}$, which corresponds to a mean aboveground biomass of $1200 \mathrm{~g} \mathrm{~m}^{\text {? }}$. This result is in agreement with literature values for Spartina maritima production: $670 \mathrm{~g} \mathrm{C} \mathrm{m}^{2} y^{\prime}$ for $200-2500 \mathrm{~g}$ $\mathrm{m}^{-2}$ aboveground biomass, in the Tagus estuary (Catarino 1981), and $296 \mathrm{~g} \mathrm{C} \mathrm{m}^{2} \mathrm{y}^{\prime}$ for a mean aboveground biomass of $628 \mathrm{~g} \mathrm{~m}^{2}$, in Bay of Biscay (Benito and Onaindia 1991).

\section{Phosphate dynamics}

In the Mondego estuary, the highest phosphate effluxes occurred in summer, which is in agreement with previous studies (Sfriso 1988, Valiela 1995, Falcão and Vale 1998, Pardal 1998, Asmus et al. 2000) showing that phosphate regeneration, into the dissolved form is dependent on temperature and redox-state of the sediment This is also evident if we compare day and night ebb tides. These effluxes are more evident in muddy bare bottom pools, followed by Spartina manitima covered pools, and by the sandy bare bottom pools. In July 97 Sportina maritima covered pool was the only one where night efflux is greater than day. This is most probably related to sediment properties such as, sediment organic content, sediment pore-water profiles of phosphate, and phosphorus adsorption capacity of the sediment (Valiela 1995. Flindt et al. 1999, Flindt et al. 2002. Martins et al. 2002). Although, as described before, the organic matter content in the sediment was higher in Spartina mantima covered pools, muddy Spartina thizosphere had also the highest adsorption capacity, $4.5 \mu \mathrm{mol}$ PO4-P $g^{\prime}$ dwt. sediment. While the bare muddy area in the same sediment depth had a capacity of $2.6 \mu \mathrm{mol} \mathrm{PO}_{4}-\mathrm{P} \mathrm{g}^{\prime}$ dwt sediment and the sandy sediment showed a capacity of only $0.97 \mu \mathrm{mol} \mathrm{PO}_{4}-\mathrm{P} \mathrm{g}^{\prime}$ dwt sediment. Furthermore, several authors (Carignan and Kalff 1980, Smart and Barko 1985, Chambers et al. 1989) have shown 
that rooted submersed macrophytes are able to uptake almost all needed phosphorus from the sediments. So, most probably, during the night ebb, when primary production does not occur and oxygen concentration in the pool decreases to anoxic levels, phosphate efflux takes place. In fact, other studies have focussed this close relation between phosphorous and oxygen concentration suggesting that under anoxic conditions sediments may tum from sinks to sources of phosphorous (Sfriso 1988. Perttilä et al. 1995).

Considering the fact that sediments constitute a major source of phosphorous supply for submersed macrophytes, during the day there might be a certain competition between two processes: Spartina maritima facilitated adsorption capacity and the efflux from the sediment, expressing the efficiency of the plants in oxidizing reduced compounds of the sediment (Caçador and Vale 2000). On the other hand this situation did not occur in November, probably as a result of decrease temperature and decrease plant activity. So. mean efflux rates were closer among the muddy pools at this time of the year. The efflux rates in the sandy pool were in the same range as recorded by Asmus et al. (2000) for Ria Formosa lagoon (Portugal) sandy sediments $\left(63-8.8 \mu \mathrm{mol} \mathrm{m}^{2} \mathrm{~h}^{\prime}\right)$, with less than I $\mathrm{m}$ water depths and similar temperature range. The efflux rates in the muddy bare bottom pool were lower but in the same range as recorded by Forja et al. (1994 in Asmus et al. 2000) for muddy sediments in the Bay of Cadiz (Spain) $\left(20.8-379.2 \mu \mathrm{mol} \mathrm{m}^{-2} \mathrm{~h}^{-1}\right)$.

This study shows that macrophytes such as Sparting maritima controls phosphate efflux from the sediment, but in absence of enough light for primary production to take place, during night, high temperatures and anoxic conditions promote phosphate efflux to the overlaying water column. On a seasonal scale, results suggest that phosphate efflux is temperature dependent and that in Spartina maritima covered pools it is also dependent on plant dynamics. Moreover, the highest mean phosphate effluxes occurred in summer with a clear contribution of the bare bottom muddy areas, which may be explained by the organic matter content and the P-sorption capacity of the plants (Flindt et al. 2002).

Taking into account these results, we hypothesised that the efflux of phosphorus in these intertidal pools could constitute an important contribution to the system internal loading of phosphorus (See Lillebø et al. 2002).

\section{Acknowledgements}

The present work was supported by the Programme MAST II (MAS 2 CT 92 0036), by the WET-project, (Wetland Ecology and Technology), funded by the European scientific TMR program. (TMR) (ERB 4061 PL 95-0832), by the F-ECTS project founded by the European Scientific MAST 3 program inside the ELOISE frame, and by the Praxis XXI program (Portugal) through a PhD grant (BD/9290/ 96). The authors would like to thank the Freshwater Biological Laboratory, University of Copenhagen, Denmark, for the support to conduct this study. 


\section{References}

Alpkem - 1990, RFA - Metholology A303-5202, A303-S170, A303-S020.ALPKEM Corporation, Clackamas. Oregon. USA.

Asmus, R.M.M. Sprung and H. Asmus. 2000. Nutrient fluxes in intertidal communities of a south European lagoon (Ria Formosa) - similanties and differences with a northern wadden sea bay (Syl-Rømø bay). Hydrobiologia. 436: 217-235.

Benito L and M. Onaindia 1991 . Biornass and aboveground production of four angiosperms in Cantabrian ( $N$. Spain) salt marshes Vegetagio 96: 165-175.

Caçador I.. C. Vale and F. Catarino 2000. Seasonal variation of $\mathrm{Zn}, \mathrm{Pb}, \mathrm{Cu}$ and $\mathrm{Cd}$ concentrations in the rootsediment system of Spartina maritima and Halimione portulocoides from Tagus estuary salt marshes. Mar. Environ. Res. 49. 279-290.

Cangnan $R$ and Kalff f. 1980. Phosphorus sources for aquatic weeds: water or sediment Science. 207: 987. 989.

Catarino, F. M. 1981. Papel das zonas húmidas do tipo sapal na descontaminação das águas. Ciência IV Série I (2): $9-16$

Chambers P.A. Prepas E.E. Bothwell M.L. and Hamiton H. R 1989. Roots versus shoots in nutrient uptake by aquatic macrophytes in flowing waters. Can. J. Fish. Aquat. Sci. 46:435-439.

Falcão, M. and C.Vale 1998. Sediment-water exchanges of ammonium and phosphate in intertidal and sutidal areas of a mesotidal coastal lagoon (Ria Formosa). Hydrobiologia. 373/374: 193: 201.

Flindt M.R and Kamp-Nielsen L 1998. The influence of sediment resuspension on nutrient metabolism in the eutrophic Roskilde Fjord, Denmark Verh. Internat Verein. Limnol. 26: 1457-1461.

Flindt, M.R. M.A. Pardal, Lillebo, A.I. Martins I. and J.C. Marques, 1999. Nutrient cycling and plant dynamic in estuaries: a brief review. Acta Oecol. 20 (4) $237-248$

Flindt. M.R. MA. Pardal, A.I. Lillebø, 1. Martins and J.M. Oliveira 2001. Nutrient dynamics in the intertidal pools of the Mondego Estuary. I - Nutrients sources, sediment profiles, mineralisation and adsorption dynamics. Aquatic Ecology of the Mondego River Basin. Global importance of local experience. (This volume)

Hinga, K.R 1990. Aiteration of phosphorous dynamics during expenmental eutrophication of enclosed marine ecosystem. Mar.Pollut. Bull. 21 (6): 275-280.

Kamp-Nielsen, L and M.R Flindt 1993. On-line recording of porewater profiles from in situ dialysis. Verh. Internat. Verein. Limnot. 25: 151.156.

Kristensen, E. 1993. Seasonal vanation in benthic community metabolism and nitrogen dynamics in a shallow, organic-poor Danish laggon. Est. Coast. Shelf Sci. 36: 565-586.

Lillebo, A.l. 2000. The effect of salt marshes plants on the nutient dynamics in the Mondego estuary (Portugal). PhD Thesis, FCT-University of Coimbra, 159p.

Lillebo. A.I. M.R. Flindt. MA. Pardal and J.C. Marques. 1999. The effect of macrofauna, meiofauna and microfauna on the degradation of Spartina maritima detritus from a salt marsh area. Acta Oecol. 20 (4) $249-258$

Lillebe A.I. M.R. Flindt., M.A. Pardal, L. Martuns, J.M. Neto and J.C. Marques 2002 Nutrient dynamics in the intertidal pools of the Mondego Estuary IV - Possible contribution to dissolved inorganic phosphorus loading. Aquatic ecology of the Mondego River Basin. Global importance of local expenence. (This volume)

270 Marques, I.C. MAS. Graça and M.A. Pardal 2002. Introducing the Mondego River Basin. Aquatic ecology of the Mondego River Basin. Global importance of local experience. (This volume)

Martins I., M.R Flindt. M.A. Pardal, A.I. Lillebø. J.M. Oliveira and J.C. Marques 2002. Nutnent dynamics in intertidal pools of the Mondego estuary. III - The importance of nutrient effluxes to macroalgal growth (Enteromorpha sp.). Aquatic ecology of the Mondego River Basin. Global importance of local experience. (This volume)

Mitchell, $\mathrm{A}$ and D.S. Baldwin 1998. Effects of Desiccation/oxidaton on the potential for bacterial mediated P release from sediments. Limnol. Oceanogr. 43 (3): $481-487$.

Ogitvie, B., D.B. Nedwell, RM. Harrison, A. Robinson and A. Sage 1997. High nitrate, muddy estuaries as nitrogen sinks: the nitrogen budget of the River Colne estuary (United Kindom). Mar. Ecol. Prog. Ser. 150: 217-228. 
Pardal, MA. 1998. Impacto da eutrofizaçăo nas comunidades macrobentónicas do braço sul do estuário do Mondego (Portugal). PhD Thesis. University of Coimbra, $315 \mathrm{p}$.

Pardal, M.A. ..C. Marques, L. Metelo, A. I. Lillebe and Flindt, M. R. 2000. Impact of eutrophication on the life cycle, population dynamics and production of Amprthoe volido (Amphipoda) along an estuanne spatial gradient (Mondego estuary. Portugal). Mar, Ecol. Prog, Ser. 196:207-279.

Perttilä M., L Niemistō and K. Mäkelä 1995. Distribution, development and total amounts of nutnents in the Gulf of Finland. Estuar. Coast. Shelf Sci. 41:345-360.

Pettine M. T. la Noce, G. Macchi, R. Pagnotta and A. Puddu 1983. factors affecting the conservation of nutrients in estuarine waters of the River Tiber. Chemistry in Ecology 1:293-309.

Rocha, C. 1998. Rhythmic ammonium regeneration and flushing in intertidal sediments of the Sado estuary. Limnol. Oceanogr. 43 (5):823-831.

Sfriso, A., B. Pavoni, A. Marcomini and A.A. Orio 1988. Annual variation of nutrients in the Lagoon of Venice. Mar. Pollut. Bull. 19 (2): 54-60.

Smart RM. and Barko J.W. 1985. laboratory culture of submersed freshwater macrophytes on natural sediments. Aquat. Bot. 21: $251-263$.

Staver, LW, KW, Staver, and J. C. Stevenson 1996. Nutnents Inputs to the Choptank River estuary Implications for Watershed management. Estuaries, 19 (2B): $342-358$.

Valiela, I and Teal, J.M. 1979. The nrtrogen budget of a salt marsh ecosystem. Nature 280:652-656.

Valiela, L. 1995. Manne Ecological Processes. 2nd ed. Springer-Verlag New York, Inc: 425-433. 
Série

Investigação

$\bullet$

Coimbra

Imprensa da Universidade

2002 